\title{
High prevalence of chronic pituitary and target-organ hormone abnormalities after blast-related mild traumatic brain injury
}

\author{
Charles W. Wilkinson ${ }^{1,2 *}$, Kathleen F. Pagulayan ${ }^{2,3}$, Eric C. Petrie ${ }^{2,3}$, Cynthia L. Mayer ${ }^{2,3}$, \\ Elizabeth A. Colasurdo ${ }^{1}$, Jane B. Shofer ${ }^{2}$, Kim L. Hart ${ }^{3}$, David Hoff ${ }^{3}$, Matthew A. Tarabochia ${ }^{3}$ and \\ Elaine R. Peskind ${ }^{2,3}$
}

\author{
' Geriatric Research, Education and Clinical Center, VA Puget Sound Health Care System, Seattle, WA, USA \\ ${ }^{2}$ Department of Psychiatry and Behavioral Sciences, University of Washington, Seattle, WA, USA \\ ${ }^{3}$ VA Northwest Network Mental IIIness Research, Education and Clinical Center, VA Puget Sound Health Care System, Seattle, WA, USA
}

\section{Edited by:}

Mattias Sköld, Uppsala University, Sweden

\section{Reviewed by:}

Ibolja Cernak, Johns Hopkins

University Applied Physics Lab, USA

Stefan Plantman, Karolinska

Institutet, Sweden

*Correspondence:

Charles W. Wilkinson, Geriatric Research, Education and Clinical Center, VA Puget Sound Health Care System, S-182 GRECC, 1660 South Columbian Way, Seattle, WA 98108, USA.

e-mail:wilkinso@uw.edu
Studies of traumatic brain injury from all causes have found evidence of chronic hypopituitarism, defined by deficient production of one or more pituitary hormones at least 1 year after injury, in $25-50 \%$ of cases. Most studies found the occurrence of posttraumatic hypopituitarism (PTHP) to be unrelated to injury severity. Growth hormone deficiency (GHD) and hypogonadism were reported most frequently. Hypopituitarism, and in particular adult GHD, is associated with symptoms that resemble those of PTSD, including fatigue, anxiety, depression, irritability, insomnia, sexual dysfunction, cognitive deficiencies, and decreased quality of life. However, the prevalence of PTHP after blast-related mild TBI (mTBI), an extremely common injury in modern military operations, has not been characterized. We measured concentrations of 12 pituitary and target-organ hormones in two groups of male US Veterans of combat in Iraq or Afghanistan. One group consisted of participants with blast-related $\mathrm{mTBI}$ whose last blast exposure was at least 1 year prior to the study. The other consisted of Veterans with similar military deployment histories but without blast exposure. Eleven of 26 , or $42 \%$ of participants with blast concussions were found to have abnormal hormone levels in one or more pituitary axes, a prevalence similar to that found in other forms of TBI. Five members of the MTBI group were found with markedly low ageadjusted insulin-like growth factor-I (IGF-I) levels indicative of probable GHD, and three had testosterone and gonadotropin concentrations consistent with hypogonadism. If symptoms characteristic of both PTHP and PTSD can be linked to pituitary dysfunction, they may be amenable to treatment with hormone replacement. Routine screening for chronic hypopituitarism after blast concussion shows promise for appropriately directing diagnostic and therapeutic decisions that otherwise may remain unconsidered and for markedly facilitating recovery and rehabilitation.

Keywords: traumatic brain injury, hypopituitarism, blast, concussion, growth hormone, pituitary

\section{INTRODUCTION}

Recent studies investigating chronic pituitary dysfunction resulting from TBI have reported a prevalence of posttraumatic hypopituitarism (PTHP) ranging from 5 to $95 \%$ with a median of $35 \%$, the variation being primarily due to differences in screening criteria (Bavisetty et al., 2008; Srinivasan et al., 2009; Berg et al., 2010; Englander et al., 2010; High et al., 2010; Kokshoorn et al., 2010, 2011; Krahulik et al., 2010; Park et al., 2010; Pavlovic et al., 2010; Reimunde et al., 2011; Schneider et al., 2011). Pituitary hormone disorders are frequently among the immediate consequences of TBI; some resolve during the following months while a smaller proportion of new dysfunctions emerge (Agha et al., 2005; Aimaretti et al., 2005; Schneider et al., 2006, 2011; Tanriverdi et al., 2006, 2008b; Klose et al., 2007; Krahulik et al., 2010). By 6 months subsequent to TBI, the pattern of pituitary deficits is considered to be relatively permanent.
The risk factors and the mechanisms, other than immediate trauma-induced tissue damage and subsequent edema, for chronic hypothalamo-pituitary dysfunction due to TBI are unclear. Roles for polymorphisms in apolipoprotein $\mathrm{E}$ genotype $(A P O E)$, inflammatory processes - both systemic and neural, and anti-hypothalamic (AHAs) and anti-pituitary antibodies (APAs) have been proposed, and each has empirical support.

There is evidence that the apolipoprotein $\mathrm{E}(A P O E) \varepsilon 3 / \varepsilon 3$ genotype may be associated with a reduced risk of TBI-related hypopituitarism. APOE $\varepsilon 3$ is the most common of the three alleles and is found in more than half of the general population. The $\varepsilon 2$ and $\varepsilon 4$ alleles have been associated with altered risks for Alzheimer's disease, hyperlipoproteinemia, and atherosclerosis. Pituitary dysfunction in patients with TBI has been found to be significantly less prevalent in individuals with the APOE $\varepsilon 3 / \varepsilon 3$ genotype (17.7\%) 
than in patients with other genotypes $(41.9 \%$; $p=0.01$; Tanriverdi et al., 2008a).

Evidence for the involvement of APAs and/or AHAs in the development of chronic PTHP comes from two studies. APAs were detected in $44.8 \%$ of patients who had completed a 3 -yearfollow-up after TBI and in none of the healthy control subjects, and the prevalence of hypopituitarism was significantly higher in APA-positive (46.2\%) than APA-negative TBI patients $(12.5 \%$; $p=0.04$; Tanriverdi et al., 2008b). In another study of active and retired boxers, AHAs were detected in $21.3 \%$ and APAs in $22.9 \%$ of boxers, whereas no evidence of APAs or AHAs was found in control subjects (Tanriverdi et al., 2010a).

It is well established that TBI results in the acute induction of both neural and systemic inflammatory responses and consequent anti-inflammatory counter-responses (Lu et al., 2009; Ziebell and Morganti-Kossmann, 2010). In addition, animal studies provide evidence of the development of a chronic inflammatory state after TBI. Three months after moderate focal brain injury in rats, persistent major histocompatibility complex (MHC)-II up-regulation, mononuclear phagocytosis, and elevated interleukin-1 $\beta$ (IL-1 $\beta$ ) and tumor necrosis factor- $\alpha$ (TNF- $\alpha$ ) synthesis were observed in large areas of the ipsilateral hemisphere (Holmin and Mathiesen, 1999). In another study, 2 months after cortical contusion injury to the medial frontal cortex of rats, IL- $1 \beta$ was significantly increased in the cortex and hypothalamus compared with a sham-trauma group, and glial fibrillary acidic protein (GFAP) was elevated in the cortex, hypothalamus, and anterior pituitary of the TBI group (Kasturi and Stein, 2009).

In general, the frequency of occurrence of pituitary hormone abnormalities has not been found to be related to the severity of the trauma (Lieberman et al., 2001; Agha et al., 2004a; Aimaretti et al., 2004, 2005; Bondanelli et al., 2004; Schneider et al., 2006; Park et al., 2010; Kokshoorn et al., 2011), although there have been reports of a positive relationship (Kelly et al., 2000; Klose et al., 2007). Of the traumatic brain injuries sustained by $\sim 1.7$ million Americans annually (Faul et al., 2010), 75\% are considered mild TBI (mTBI; National Center for Injury Prevention and Control, 2003).

Mild TBI is defined by the American Congress of Rehabilitation Medicine (ACRM) as a head trauma resulting in any one of the following: loss of consciousness (LOC) for $30 \mathrm{~min}$ or less, alteration of mental state for up to $24 \mathrm{~h}$ (being dazed, confused, disoriented, etc.), or loss of memory for events immediately before or after the trauma (American Congress of Rehabilitation Medicine, 1993). The terms mTBI and concussion are frequently used interchangeably (National Center for Injury Prevention and Control, 2003; Department of Veterans Affairs/Department of Defense, 2009).

Mild TBI-related chronic pituitary dysfunction has been reported in boxers and kick boxers subjected to repetitive head injuries. In a preliminary study, $45 \%$ of professional boxers were found with apparent growth hormone deficiency (GHD), but no other pituitary hormone deficiencies were observed (Kelestimur et al., 2004). In a larger study of active and retired boxers $18 \%$ had pituitary hormone deficiencies in one or more axes (Tanriverdi et al., 2008c). An investigation of pituitary dysfunction in amateur kick boxers revealed GH and/or adrenocorticotropin (ACTH) deficiencies in $27.3 \%$ of the athletes (Tanriverdi et al., 2007).

In 2010 , the injuries in $80 \%$ of over 30,000 U.S. military service members medically diagnosed with TBI were classified as
mTBI (Military Health System, 2011), and mTBI sustained from explosive blasts is one of the most common combat injuries resulting from deployment to Iraq or Afghanistan. About $10-20 \%$ of returnees report having experienced at least one blast concussion (Tanielian et al., 2008; Terrio et al., 2009).

The extensive documentation of the high prevalence of hypopituitarism after TBI from all causes and the absence of any published studies of the frequency of PTHP after blast-related mTBI provided the rationale for this investigation of hypopituitarism in U.S. Veterans of combat in Iraq and/or Afghanistan who have experienced at least one blast concussion.

\section{MATERIALS AND METHODS}

\section{PARTICIPANTS AND SAMPLE ACOUISITION}

The VA Puget Sound Health Care System (VAPSHCS) Institutional Review Board and the U.S. Army Medical Research and Materiel Command (USAMRMC) Office of Research Protections (ORP) Human Research Protection Office (HRPO) approved the subject protocol with a waiver of informed consent. All plasma and serum samples, demographic, and blast exposure data were obtained from an established biorepository entitled "Alzheimer's Disease Research Center (ADRC) Participant Registry and Sample Repository." All subjects whose samples were utilized had consented to have their samples and data used in future research of this type.

The mTBI Veteran participants (T group) whose samples were obtained from the repository were a convenience sample of 26 male Veterans recruited from VAPSHCS, all of whom had documented hazardous duty experience in Iraq and/or Afghanistan with the U.S. Armed Forces and had reported experiencing at least one blast exposure in the war zone that resulted in acute mTBI as defined by ACRM criteria (American Congress of Rehabilitation Medicine, 1993) except that Glasgow Coma Scale scores were not obtained in the combat setting. Samples from the repository were also collected from seven male Veterans who had been deployed to Iraq and/or Afghanistan but who had not been exposed to blast and had no history of TBI. These individuals made up the deployment control (DC) group.

Additional samples from the repository which were used to establish normal hormonal reference ranges had been collected from 59 cognitively normal male community volunteers recruited from the ADRC, all of whom were medically healthy and had MiniMental State Examination scores of $29.4 \pm 1.0$ (mean \pm SEM; range 27-30); Clinical Dementia Rating scores of zero; no evidence or history of cognitive or functional decline; and no history of blast exposure or head injury. These samples were used only for the establishment of normative hormone concentrations with our assay methods. Resting blood samples had been collected from all participants between 9:00 and 10:00 a.m., at least $30 \mathrm{~min}$ after the insertion of an intravenous catheter in an antecubital vein.

None of the Veteran or community control participants had a history of blast exposure, head injury with LOC greater than $30 \mathrm{~min}$; penetrating head wound; seizure disorder; insulindependent diabetes; current or past DSM-IV diagnoses of schizophrenia, other psychotic disorders, bipolar disorder, or dementia; or a DSM-IV diagnosis of alcohol or other substance abuse or dependence within the previous 3 months. Participants using medications likely to affect brain function, such as opioids, 
benzodiazepines, or anti-depressants, were asked not to take those medications for $24 \mathrm{~h}$ prior to blood sampling.

\section{BLAST EXPOSURE ASSESSMENT}

Blast exposure and mTBI histories had been obtained from mTBI Veteran participants during a clinical interview in which specific inquiries were made regarding total number of blast exposures accompanied by acute symptoms of TBI and/or LOC in Iraq and/or Afghanistan and lifetime history of non-blast exposure head injuries accompanied by acute symptoms of TBI and/or LOC (e.g., sports or motor vehicle accident-related concussion).

\section{NEUROLOGICAL ASSESSMENT}

All subjects underwent a full neurological examination, including the Unified Parkinson's Disease Rating Scale (UPDRS) motor section (Martínez-Martín et al., 1994). Olfactory function was assessed using the Brief Smell Identification Test (B-SIT; Doty et al., 1996).

\section{HORMONE MEASUREMENT}

Blood samples for the measurement of plasma hormone concentrations were collected between 9:00 and 10:00 a.m. in chilled tubes containing ethylenediaminetetraacetic acid (EDTA), placed on ice, and centrifuged at $4^{\circ} \mathrm{C}$ prior to removal of the plasma fraction. Blood samples for measurement of serum hormones were collected in serum-separator tubes, allowed to clot at room temperature for $10 \mathrm{~min}$, and centrifuged to isolate serum. Serum and plasma samples were aliquoted and stored at $-70^{\circ} \mathrm{C}$. Twelve pituitary or target-organ hormones were measured in these samples. The type, source, and performance characteristics of the assay kits used for the measurement of hormone concentrations in serum and plasma are shown in Table 1. ACTH, cortisol, thyroidstimulating hormone (TSH), oxytocin, and vasopressin concentrations were determined in plasma; free thyroxine, luteinizing hormone ( $\mathrm{LH})$, follicle-stimulating hormone (FSH), total testosterone, insulin-like growth factor-I (IGF-I), growth hormone, and prolactin were measured in serum.

\section{CLINICAL LAB DATA}

Measurements of plasma and urine osmolality were not available but urine specific gravity was measured and used as a criterion to determine functional vasopressin insufficiency.

\section{STATISTICAL ANALYSIS AND CRITERIA FOR PITUITARY DEFICIENCIES}

The criteria for PTHP, derived using hormone measurements from the 59 community control participants are shown in Table 2. For each hormone, age-adjusted percentiles based on the lognormal distribution from community control participants were estimated and dysfunction in each of seven hormonal axes was defined ( $R$ Development Core Team, 2011). Hypopituitarism was defined as a dysfunction in at least one of these seven axes. These criteria were

Table 1 | Sources and characteristics of hormone assay kits.

\begin{tabular}{|c|c|c|c|c|c|c|c|c|}
\hline Assay & \multicolumn{4}{|c|}{ Kit name } & \multicolumn{2}{|c|}{ Manufacturer } & \multicolumn{2}{|c|}{ Location } \\
\hline ACTH & \multicolumn{4}{|c|}{ ACTH Immunoradiometric (IRMA) Assay } & \multicolumn{2}{|c|}{ Scantibodies Laboratory } & \multicolumn{2}{|c|}{ Santee, CA, USA } \\
\hline Cortisol & \multicolumn{4}{|c|}{ GammaCoat ${ }^{\mathrm{TM}}$ Cortisol ${ }^{125}$ I RIA } & \multicolumn{2}{|c|}{ Diasorin } & \multicolumn{2}{|c|}{ Stillwater, MN, USA } \\
\hline $\mathrm{FSH}$ & \multicolumn{4}{|c|}{ DELPHIA hFSH } & \multicolumn{2}{|l|}{ Perkin Elmer } & \multicolumn{2}{|c|}{ Waltham, MA, USA } \\
\hline $\mathrm{GH}$ & \multicolumn{4}{|c|}{ hGH-ELISA, Ultra-Sensitive } & \multicolumn{2}{|l|}{ DSL } & \multicolumn{2}{|c|}{ Webster, TX, USA } \\
\hline |GF-| & \multicolumn{4}{|l|}{ IGF-I RIA } & \multicolumn{2}{|l|}{ IBL America } & \multicolumn{2}{|c|}{ Minneapolis, MN, USA } \\
\hline $\mathrm{LH}$ & \multicolumn{4}{|c|}{ ImmuChem ${ }^{\mathrm{TM}}$ Coated Tube LH ${ }^{125}$ I RIA } & \multicolumn{2}{|c|}{ MP Biomedicals } & \multicolumn{2}{|c|}{ Costa Mesa, CA, USA } \\
\hline Oxytocin & \multicolumn{4}{|c|}{ Oxytocin EIA Kit - Extraction-free } & \multicolumn{2}{|c|}{ Peninsula Labs/Bachem } & \multicolumn{2}{|c|}{ San Carlos, CA, USA } \\
\hline Prolactin & \multicolumn{4}{|c|}{ ImmuChem ${ }^{\mathrm{TM}}$ Coated Tube Prolactin ${ }^{125}$ I IRMA } & \multicolumn{2}{|c|}{ MP Biomedicals } & \multicolumn{2}{|c|}{ Costa Mesa, CA, USA } \\
\hline Testosterone & \multicolumn{4}{|c|}{ Total Testosterone } & \multicolumn{2}{|c|}{ Siemens Diagnostics } & \multicolumn{2}{|c|}{ Los Angeles, CA, USA } \\
\hline Thyroxine & \multicolumn{4}{|c|}{ Free Thyroxine $\left(\mathrm{FT}_{4}\right)$ Microplate EIA } & MP Biomed & als & Costa & Mesa, CA, USA \\
\hline TSH & ImmuCh & $\mathrm{m}^{\mathrm{TM}}$ Coated Tub & $\mathrm{TSH}^{125}$ I IRN & & MP Biomed & als & Costa & Mesa, CA, USA \\
\hline Vasopressin & Vasopres & in Direct RIA & & & ALPCO & & Salem & $\mathrm{NH}, \mathrm{USA}$ \\
\hline Hormones & Assay type & Sample type & Assay size & Sample size & Assay range & Sensitivity & Intra-assay CV & Inter-assay CV \\
\hline ACTH & IRMA & Plasma & 100 Tubes & $200 \mu l$ & 9-1693 pg/ml & $<1.0 \mathrm{pg} / \mathrm{ml}$ & 4.05 & 6.66 \\
\hline Cortisol & RIA & Plasma & 100 Tubes & $10 \mu \mid$ & $1-60 \mu \mathrm{g} / \mathrm{dl}$ & $0.21 \mu \mathrm{g} / \mathrm{dl}$ & 7.03 & 9.20 \\
\hline $\mathrm{FSH}$ & Fluoroimmunoassay & Serum & 96 Wells & $25 \mu l$ & $0.98-256 \mathrm{U} / \mathrm{I}$ & $0.05 \mathrm{U} / \mathrm{l}$ & 2.33 & 1.87 \\
\hline $\mathrm{GH}$ & EIA & Serum & 96 Wells & $100 \mu l$ & 4.5-500 pg/ml & $0.66 \mathrm{pg} / \mathrm{ml}$ & 6.00 & 5.40 \\
\hline IGF-1 & RIA & Serum & 100 Tubes & $100 \mu l$ & $0.16-10.0 \mathrm{ng} / \mathrm{ml}$ & $0.02 \mathrm{ng} / \mathrm{ml}$ & 2.97 & 10.30 \\
\hline $\mathrm{LH}$ & RIA & Serum & 100 Tubes & $100 \mu l$ & $2.5-200 \mathrm{mlU} / \mathrm{ml}$ & $1.5 \mathrm{mlU} / \mathrm{ml}$ & 5.90 & 7.90 \\
\hline Oxytocin & EIA & Plasma & 96 Wells & $50 \mu l$ & 0-630 pg/ml & $6.5 \mathrm{pg} / \mathrm{ml}$ & 9.36 & 13.67 \\
\hline Prolactin & IRMA & Serum & 100 Tubes & $25 \mu l$ & $2.5-100 \mathrm{ng} / \mathrm{ml}$ & $2.5 \mathrm{ng} / \mathrm{ml}$ & 5.13 & 8.08 \\
\hline Testosterone & Solid-phase RIA & Serum & 100 Tubes & $50 \mu l$ & 20-1600 ng/dl & $4 \mathrm{ng} / \mathrm{dl}$ & 3.40 & 7.90 \\
\hline Thyroxine & EIA & Serum & 96 Wells & $50 \mu 1$ & $0.45-7.6 \mathrm{ng} / \mathrm{dl}$ & $0.05 \mathrm{ng} / \mathrm{dl}$ & 6.83 & 6.47 \\
\hline $\mathrm{TSH}$ & IRMA & Plasma & 100 Tubes & $200 \mu l$ & $0.2-50 \mu \mathrm{IU} / \mathrm{ml}$ & $0.04 \mu \mathrm{IU} / \mathrm{ml}$ & 4.10 & 5.23 \\
\hline Vasopressin & $\mathrm{RIA}$ & Plasma & 100 Tubes & $400 \mu l$ & $1.25-80 \mathrm{pg} / \mathrm{ml}$ & $0.1 \mathrm{pg} / \mathrm{ml}$ & 6.00 & 9.90 \\
\hline
\end{tabular}


Table 2 | Screening criteria for identifying abnormal circulating hormone levels.

\section{Axis}

Adrenal insufficiency

Thyroid deficiency

Hypogonadism

Vasopressin abnormality

Prolactin abnormality

$\mathrm{GH}$ deficiency

Oxytocin deficiency

Hypopituitarism

Criteria using lognormal distribution of community control reference sample

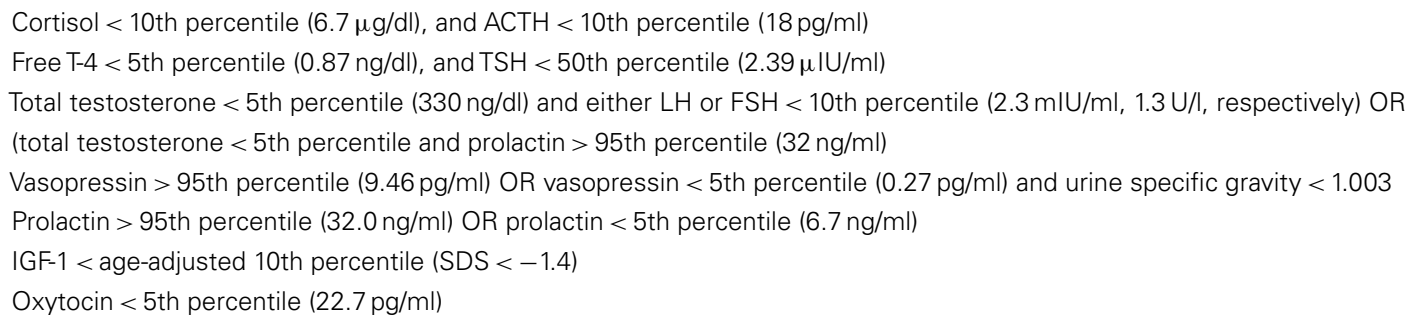

Abnormalities in at least one of these 7 axes

modeled after those used in published studies of hypopituitarism after TBI from all causes.

\section{RESULTS}

\section{PLASMA/SERUM HORMONE SCREENING EVALUATIONS}

Eleven of 26 mTBI subjects ( T), or 42\%, were found to have abnormal hormone values in at least one axis. As reported in earlier studies of PTHP, deficiencies in the growth hormone-IGF-I and pituitary-gonadal axes were observed most frequently (Bavisetty et al., 2008; Dusick et al., 2008; Schneider et al., 2008; Englander et al., 2010; Kokshoorn et al., 2010; Krahulik et al., 2010; Park et al., 2010; Pavlovic et al., 2010; van der Eerden et al., 2010).

Markedly low IGF-I levels are strong indicators of adult GHD (Juul et al., 1997; Hartman et al., 2002; Hadjadj et al., 2007; Ho, 2007; Prodam et al., 2008; Tanriverdi et al., 2011; Zgaljardic et al., 2011). The red line in Figure 1 represents the cutoff level used to define our criterion for subnormal IGF-I levels indicative of probable GHD. The cutoff level was defined to be an IGF-I concentration below the age-adjusted 10th percentile level [equivalent to an SD score (SDS) below -1.4] of the community control reference sample (Figure 1; Table 2). Five Veteran participants with mTBI (T-4, $\mathrm{T}-8, \mathrm{~T}-16, \mathrm{~T}-25$, and T-28) were found to have serum IGF-I concentrations below this cutoff line. None of the Veteran participants in the DC group were found to have subnormal age-adjusted IGF-I levels (Figure 1).

Three participants with mTBI (T-4, T-13, and T-28) were found with abnormal hormonal profiles indicating probable hypogonadism. The criteria were a total testosterone concentration less than the 5 th percentile of the reference sample together with an LH or FSH level below the 10th percentile reference level (Figure 2; Table 2). T-4 and T-28 also had the lowest two IGF-I levels among the participants (T-4: $126 \mathrm{ng} / \mathrm{ml}, \mathrm{SDS}=-2.325 ; \mathrm{T}-28: 86 \mathrm{ng} / \mathrm{ml}$, $\mathrm{SDS}=-2.989$ ). Elevated prolactin levels in conjunction with low testosterone are also indicative of hypogonadism. A serum prolactin concentration markedly higher than the 95th percentile of the reference sample was found in serum from participant T-4. A subnormal prolactin concentration ( $<5$ th percentile), also associated with sexual dysfunction, was measured in serum from T-13.

None of the Veterans in the DC group were found to have hormone levels indicative of hypogonadism. One participant in the DC group was found with a total testosterone concentration below the 5th percentile reference standard and another had an LH

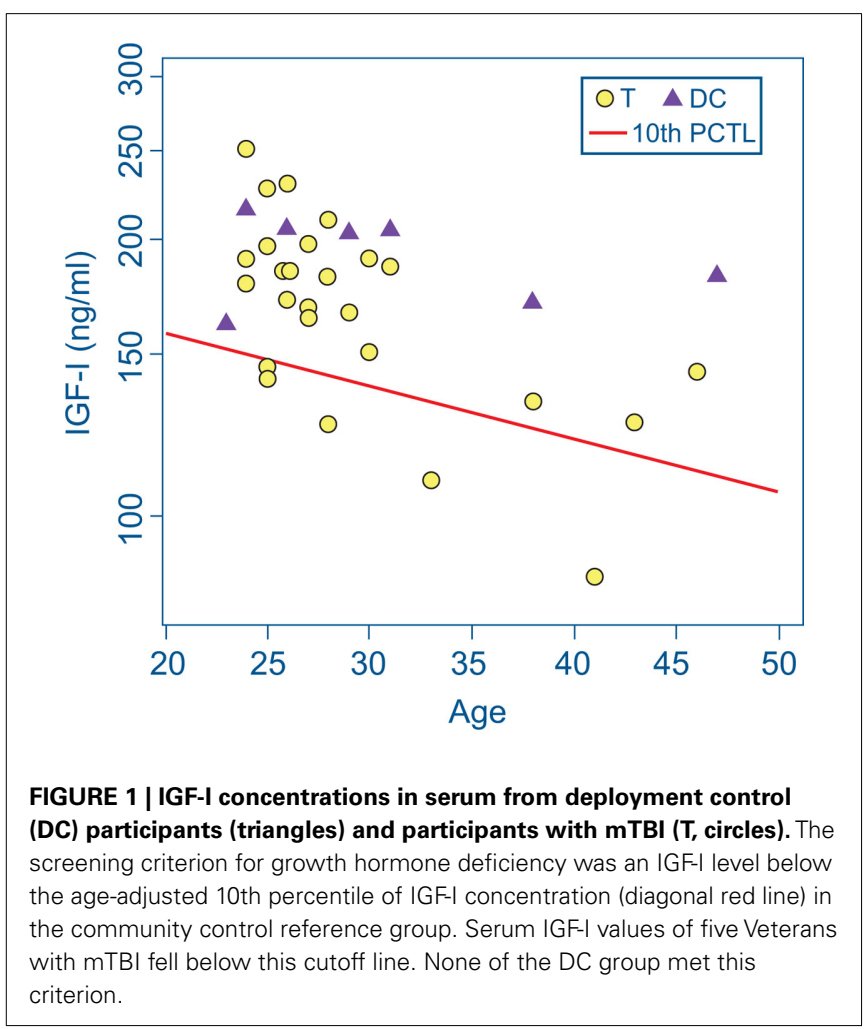

concentration below the 10th LH percentile, but neither exhibited the combined gonadotropin and testosterone deficiencies consistent with hypogonadism.

None of the Veteran participants in either the $\mathrm{T}$ or $\mathrm{DC}$ group exhibited abnormalities in the hypothalamic-pituitaryadrenocortical or hypothalamic-pituitary-thyroid axis (Table 3). The corticotrophs and thyrotrophs are located in the protected median wedge of the anterior pituitary and are anatomically less vulnerable to injury than gonadotropin- and GH-secreting cells. This differential anatomical vulnerability correlates well with the frequency of chronic hormonal abnormalities observed after TBI (Bavisetty et al., 2008; Blair, 2010; Krahulik et al., 2010).

In addition to the findings of anterior pituitary hormone abnormalities in six Veteran participants with mTBI, eight instances of anomalous posterior pituitary hormone levels were 


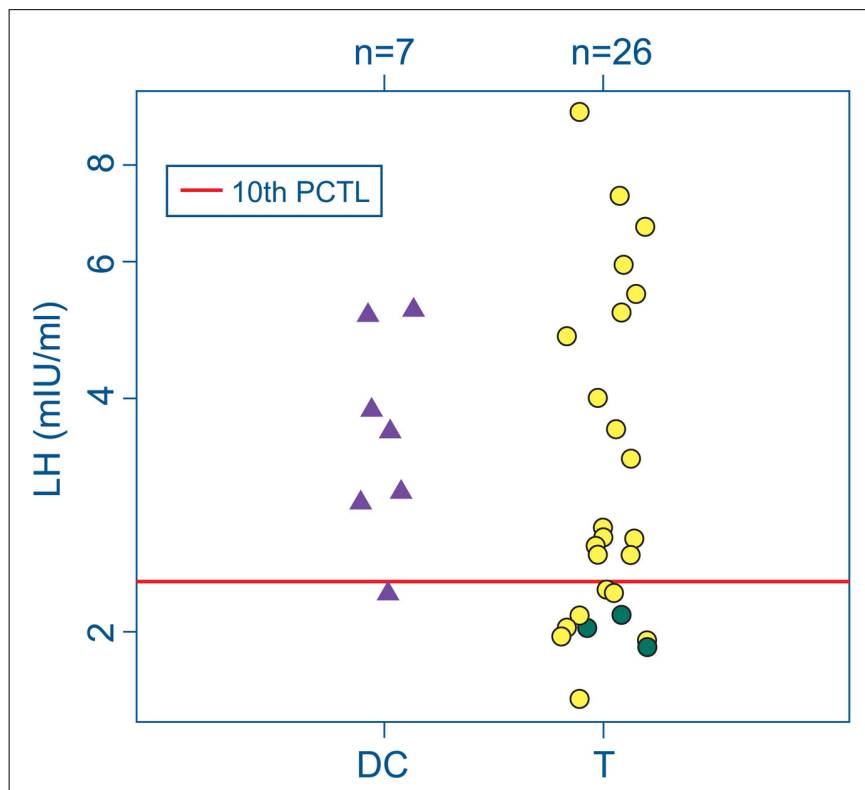

FIGURE 2 | Serum LH (left) and testosterone (right) in the deployment control (DC, triangles) and $\mathrm{mTBI}$ (T, circles) groups. Screening criteria for hypogonadism: LH (or FSH) levels below the 10th percentile of the control found in six Veterans in the mTBI group, one of whom, T-28, also had evidence of presumptive GHD and hypogonadism. The plasma oxytocin concentration was unmeasurably low in this individual (Table 3). None of the Veterans in the DC group were found to have abnormal posterior pituitary hormone values.

Three additional participants from the mTBI group ( $\mathrm{T}-10$, $\mathrm{T}-14$, and $\mathrm{T}-22$ ) also were found to have circulating oxytocin concentrations below the reference sample's 5th percentile level. Two of these participants, T-10 and T-22, also met our criteria for arginine vasopressin (AVP) deficiency: plasma vasopressin concentration below the 5th percentile of the reference level in combination with urine specific gravity less than 1.003. In addition, plasma vasopressin concentrations in participants T-2 and T-12 were abnormally elevated above the 95th percentile of the reference group.

\section{DEMOGRAPHICS, DEPLOYMENT HISTORY, BLAST EXPOSURE, AND MEDICATION USE}

After completion of hormone measurement and identification of Veterans with apparent hypopituitarism, participants in the $\mathrm{T}$ group were divided into two subgroups, based on the presence or absence of hormone abnormalities, for comparison of demographic, deployment history, blast exposure, and medication use data with each other and with the DC group. The three groups of Veteran participants did not differ in age, education, or body mass index at the time of enrollment, and the two mTBI subgroups did not differ significantly from one another on any of the measures of deployment history or blast exposure (Table 4).

\section{CONCURRENT MEDICATIONS}

Medications with potential neuroendocrine effects taken by mTBI subjects found to have indications of hypopituitarism were opiates $(2 / 11)$, prazosin $(2 / 11)$, selective serotonin reuptake inhibitors

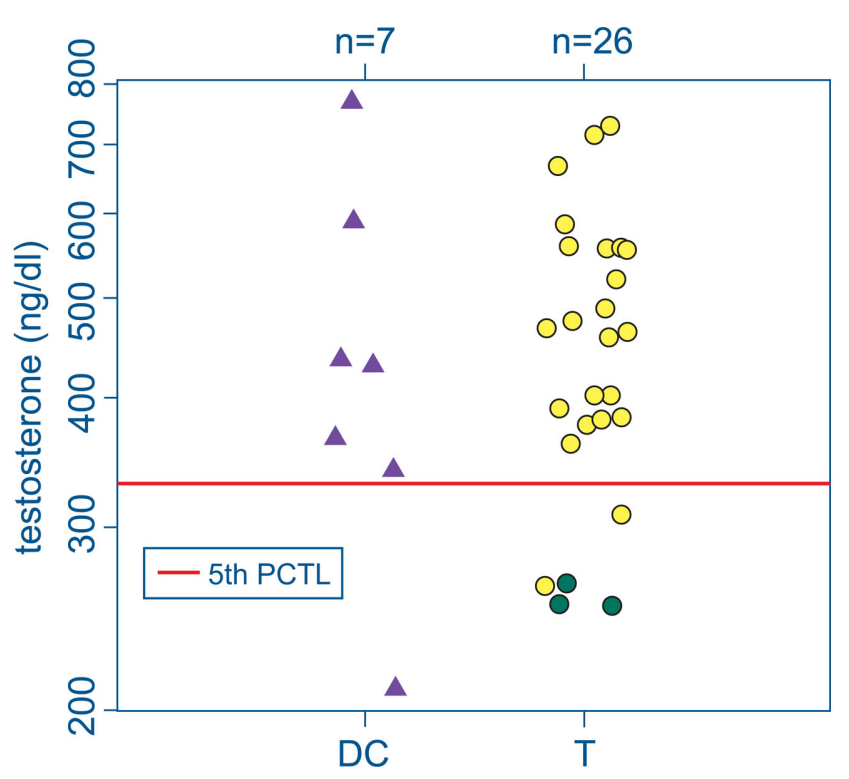

range together with testosterone below the 5th percentile (red lines). Green circles mark data from 3 T subjects falling below both cutoffs. No DC subjects met both criteria.

(SSRIs; 4/11), serotonin and norepinephrine reuptake inhibitors (SNRIs; 2/11), hypnotics (2/11), atypical antipsychotics (1/11), calcium channel blockers for migraine (1/11), benzodiazepines $(1 / 11)$, and mirtazapine (1/11). Five subjects in this group were not taking any neuroactive medications. Medications with potential neuroendocrine effects taken by mTBI subjects found to have hormone levels within normal ranges were opiates $(1 / 15)$, prazosin (4/15), SSRIs (3/15), SNRIs (2/15), mirtazapine (1/15), trazodone (1/15), benzodiazepines (1/15), and disulfiram (1/15). Nine subjects in this group were not taking any neuroactive medications. Medications with potential neuroendocrine effects taken by DC subjects were opiates (1/7), SSRIs (1/7), and SNRIs (1/7). Five subjects in this group were not taking any neuroactive medications.

\section{DISCUSSION}

Our findings in this preliminary study support the hypothesis that blast mTBI carries a risk of PTHP similar to that found in several previous studies of hypopituitarism in the general population after TBI from all causes. We have found that blood samples from 11 of 26 , or $42 \%$ of Veterans of combat in Iraq or Afghanistan had abnormal circulating hormone concentrations consistent with PTHP. Five participants with blast mTBI exhibited evidence of anterior pituitary dysfunction, five additional subjects had anomalous posterior pituitary hormone levels, and the eleventh was found to have both anterior and posterior pituitary hormonal abnormalities. In contrast, none of the seven Veterans of deployment to Iraq and/or Afghanistan in the study who did not experience blast trauma - the DC group - were found to have evidence of pituitary dysfunction.

As Kokshoorn et al. (2010) pointed out in their review of 14 investigations of PTHP conducted between 2000 and 2009, these early studies used a broad variety of screening criteria that were sometimes described in general terms rather than with specifically 
Table 3 | Plasma or serum hormone concentration for each participant.

\begin{tabular}{|c|c|c|c|c|c|c|c|c|c|c|c|c|c|c|}
\hline Subject & Age & \#BE & $\begin{array}{l}\text { АCTH } \\
(\mathrm{pg} / \mathrm{ml})\end{array}$ & $\begin{array}{l}\text { Cort } \\
(\mu \mathrm{g} / \mathrm{dl})\end{array}$ & $\begin{array}{l}\text { LH } \\
\text { (mlU/ml) }\end{array}$ & $\begin{array}{l}\text { FSH } \\
\text { (U/I) }\end{array}$ & $\begin{array}{l}\text { tTest } \\
\text { (ng/dl) }\end{array}$ & $\begin{array}{l}\text { PRL } \\
\text { (ng/ml) }\end{array}$ & $\begin{array}{l}\text { TSH } \\
(\mu \mathrm{IU} / \mathrm{ml})\end{array}$ & $\begin{array}{l}\text { fT-4 } \\
\text { (ng/dl) }\end{array}$ & $\begin{array}{l}\text { IGF-I } \\
\text { (ng/ml) }\end{array}$ & $\begin{array}{l}\text { GH } \\
(\mathrm{pg} / \mathrm{ml})\end{array}$ & $\begin{array}{l}\text { AVP } \\
(\mathrm{pg} / \mathrm{ml})\end{array}$ & $\begin{array}{l}\text { OT } \\
\text { (pg/ml) }\end{array}$ \\
\hline $\mathrm{T}-1$ & 24 & 11 & 24 & 6.6 & 2.58 & 0.46 & 473 & 12.5 & 1.70 & 1.29 & 190 & 58 & 3.4 & 64 \\
\hline $\mathrm{T}-2$ & 26 & 6 & 20 & 11.9 & 2.03 & - & 669 & 9.6 & 1.92 & 1.67 & 185 & 71 & 12.3 & 181 \\
\hline T-3 & 27 & 10 & 22 & 10.2 & 5.15 & 2.05 & 557 & 13.0 & 1.59 & 1.59 & 164 & 50 & 4.0 & 166 \\
\hline $\mathrm{T}-4$ & 33 & 15 & 19 & 7.5 & 2.03 & 2.06 & 252 & 54.9 & 1.17 & 1.22 & 110 & 11 & 8.0 & 88 \\
\hline$T-5$ & 38 & 102 & 24 & 12.8 & 2.11 & 2.33 & 362 & 14.9 & 1.16 & 1.18 & 133 & 0 & 0.4 & 71 \\
\hline T-6 & 46 & 5 & 29 & 12.1 & 1.95 & 1.41 & 402 & 11.1 & 1.08 & 1.09 & 143 & 152 & 0.7 & 61 \\
\hline $\mathrm{T}-7$ & 26 & 20 & 28 & 14.1 & 3.34 & 1.63 & 559 & 12.0 & 2.26 & 1.29 & 172 & 223 & 0.0 & 39 \\
\hline T-8 & 25 & 21 & 35 & 11.3 & 2.72 & 4.02 & 401 & 11.9 & 1.13 & 1.55 & 141 & 294 & 0.2 & 44 \\
\hline T-9 & 24 & 102 & 39 & 12.0 & 4.81 & 3.28 & 730 & 14.4 & 1.16 & 1.05 & 251 & 1288 & 8.0 & 52 \\
\hline$T-10$ & 26 & 20 & 30 & 9.6 & 1.97 & 2.43 & 520 & 12.3 & 2.41 & 1.39 & 230 & 68 & 0.2 & 22 \\
\hline $\mathrm{T}-11$ & 28 & 9 & 31 & 10.2 & 1.64 & 2.38 & 382 & 9.2 & 1.30 & 1.22 & 182 & 0 & 1.1 & 36 \\
\hline T-12 & 27 & 15 & 27 & 9.9 & 7.27 & 5.70 & 715 & 13.0 & 1.57 & 1.38 & 198 & 60 & 12.0 & 55 \\
\hline T-13 & 31 & 7 & 40 & 7.8 & 1.92 & 1.18 & 253 & 6.3 & 2.24 & 1.14 & 187 & 0 & 6.4 & 50 \\
\hline T-14 & 30 & 6 & 36 & 8.8 & 2.66 & 2.51 & 390 & 12.0 & 3.75 & 1.13 & 151 & 310 & 0.5 & 19 \\
\hline T-15 & 27 & 11 & 16 & 7.4 & 2.27 & 3.56 & 377 & 10.1 & 1.40 & 1.14 & 168 & 42 & 4.4 & 85 \\
\hline T-16 & 28 & 66 & 25 & 11.7 & 2.64 & 4.01 & 380 & 21.5 & 0.65 & 1.52 & 126 & 0 & 0.9 & 190 \\
\hline T-17 & 25 & 18 & 26 & 11.2 & 9.32 & 3.00 & 465 & 17.1 & 1.26 & 1.25 & 197 & 0 & 4.8 & 151 \\
\hline T-18 & 24 & 7 & 30 & 14.2 & 3.65 & 2.21 & 556 & 12.2 & 1.27 & 1.30 & 179 & 60 & 4.3 & 32 \\
\hline T-19 & 30 & 1 & 32 & 18.6 & 5.44 & 3.01 & 457 & 11.7 & 1.55 & 1.13 & 190 & 66 & 0.0 & 46 \\
\hline $\mathrm{T}-20$ & 28 & 3 & 17 & 25.0 & 6.65 & 3.91 & 309 & 10.4 & 0.79 & 1.31 & 210 & 1696 & 7.9 & 519 \\
\hline T-22 & 25 & 4 & 21 & 17.6 & 4.00 & 4.48 & 588 & 12.8 & 1.09 & 1.24 & 227 & 110 & 0.0 & 21 \\
\hline T-23 & 29 & 52 & 11 & 8.7 & 2.52 & 2.55 & 554 & 8.9 & 1.34 & 1.35 & 166 & 95 & 4.0 & 199 \\
\hline T-25 & 25 & 12 & 8 & 7.7 & 2.24 & 4.34 & 463 & 7.2 & 1.42 & 1.23 & 146 & 813 & 2.1 & 25 \\
\hline T-26 & 26 & 11 & 9 & 6.8 & 5.94 & 1.14 & 488 & 8.4 & 0.81 & 1.18 & 185 & 42 & 0.9 & 457 \\
\hline $\mathrm{T}-27$ & 43 & 5 & 29 & 7.5 & 2.52 & 3.89 & 263 & 7.1 & 0.60 & 1.04 & 126 & 13 & 2.6 & 50 \\
\hline T-28 & 41 & 12 & 15 & 11.1 & 2.11 & 2.64 & 264 & 15.3 & 1.22 & 1.11 & 86 & 375 & 8.4 & 0 \\
\hline
\end{tabular}

Shaded values indicate hormone axis abnormalities as defined in Table 2. \#BE, number of self-reported blast exposures meeting ACRM criteria for mTBI during military career; ACTH, adrenocorticotropin; Cort, cortisol; LH, luteinizing hormone; FSH, follicle-stimulating hormone; tTest, total testosterone; PRL, prolactin; TSH, thyroid-stimulating hormone; fT-4, free thyroxine; IGF-I, insulin-like growth factor-l; GH, growth hormone; AVP, vasopressin; OT, oxytocin.

defined cutoffs. We attempted to use relatively conservative and explicitly defined criteria based on the distribution of specific hormone concentrations measured in a reference population. We did not employ provocative testing but used criteria based on measurement of both pituitary hormones and their target-organ hormones when possible, e.g., a combination of measurements of total testosterone, LH, FSH, and prolactin to screen for hypogonadism.

It should be cautioned that the determinations of basal hormone concentrations, such as those made in this study, are meant to be screening tools, and are not intended to be, nor should they be interpreted to be, diagnostic in the absence of clinical assessment. Measurement of basal circulating hormone concentrations is generally considered an appropriate screening tool for provisional identification of deficient thyroid function, hypogonadism, and prolactin and oxytocin deficiencies. Diagnosis of significant abnormalities of vasopressin secretion normally require confirmation by measures of plasma and/or urine osmolality, urine specific gravity (UGS), and/or the administration of a water deprivation test. Although provocative testing is generally considered necessary for diagnosis of sAI and GHD, measurement of basal cortisol and IGF-I concentrations remain valuable screening tools to identify individuals most likely to benefit from additional testing and clinical referral. Evaluation of clinical signs and symptoms are essential for definitive diagnoses in all cases.

Previous studies have found GHD to be the most prevalent chronic endocrine consequence of TBI, and it carries with it a potentially large range of symptoms. Provocative testing is considered to be a requisite for the reliable diagnosis of GHD because serum GH concentrations measured in the morning are not valid indicators of daily secretion or somatotroph function. GH secretion occurs predominantly during sleep, and morning levels are generally very low but punctuated unpredictably by short secretory bursts (Van Cauter et al., 1992). However, GH stimulates hepatic production of IGF-I that provides a useful index of somatotroph function. IGF-I concentrations have low diagnostic sensitivity for identifying GHD but are highly specific. The presence of normal IGF-I values cannot be used to exclude GDH because it is often diagnosed in individuals with normal or even elevated IGF-I levels. However, markedly low age-adjusted levels of IGF-I are strongly indicative of GHD (Juul et al., 1997; Hadjadj et al., 2007; Ho, 2007; Prodam et al., 2008; Tanriverdi et al., 2011; Zgaljardic et al., 2011). Circulating IGF-I concentrations decline markedly with increasing age, and this decline must be taken into account when interpreting them. 
Table 4 | Mean \pm SEM and (range) for demographic, deployment, and blast exposure data for each group of participants.

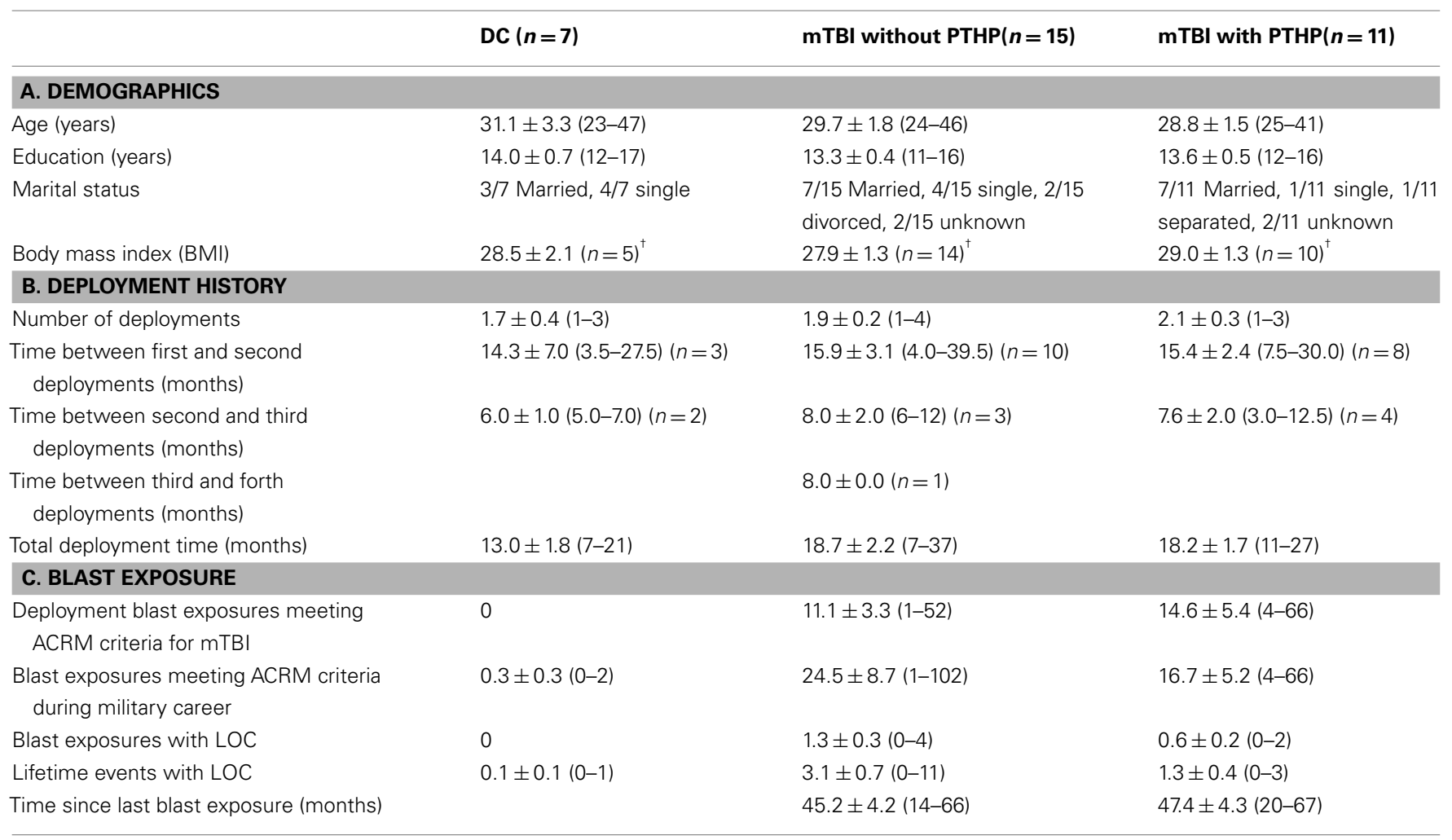

The Veterans with blast MTBI (T group) were divided into two subgroups based upon the presence or absence of abnormal hormonal profiles suggesting PTHP. ${ }^{\dagger} B M I S$ were not obtained for all participants.

Studies using receiver operating characteristic (ROC) analysis to compare the diagnostic accuracy of IGF-I relative to diagnosis of GHD based on provocative testing of GH secretion have reported a diagnostic specificity of $100 \%$ with IGF-I SDS cutoffs of -1.3 (Corneli et al., 2007) or -1.7 (Maghnie et al., 2005).

The individuals classified here as having a high probability of GHD all had values less than -1.4 SDs below the age-adjusted means of the reference sample. The high specificity of IGF-I measurements at this level assures a very low likelihood of false positives in diagnosing GHD. However, in light of the low sensitivity of IGF-I concentrations in predicting GHD, it is probable that some Veteran participants with normal IGF-I levels may be growth hormone deficient.

The long-term sequelae of GHD in adults for health, quality of life (QoL), and morbidity are multifaceted and complex. Low GH secretion has been associated with behavioral symptoms and deficits in several cognitive domains (Popovic et al., 2004; Falleti et al., 2006; Pavlovic et al., 2010). GHD also has significant deleterious effects on body composition and cardiovascular function. Adult GHD is associated with lipidemia, reduced lean body mass, and increased adiposity. Even partial GHD in adult patients is associated with adverse lipid profiles and early atherosclerosis (Colao et al., 2006a,b; Colao, 2008). Impairment in QoL is also a prominent feature of adult GHD, especially in the areas of energy and vitality (McGauley, 1989; Kelly et al., 2006; Bushnik et al., 2007; Svensson et al., 2007; Bavisetty et al., 2008). Adult
GHD is also associated with reductions in muscle volume and strength, decreased physical mobility, fatigue, sleep impairment, social isolation, depression, lowered metabolic rate, low sexual drive, and reduced aerobic capacity (Rosén et al., 1994; Mossberg et al., 2008).

Many of the symptoms of GHD can be successfully ameliorated or reversed by growth hormone replacement therapy. Five retrospective studies have shown that the risk of premature death from cardiovascular disease is elevated in patients with GHD (Svensson et al., 2004a). The increased risk factors such as adverse lipid profiles, increased blood pressure, abnormal body composition, increased body weight, increased coagulability, and increased markers of inflammation have all been shown to improve with GH replacement (Svensson et al., 2004a, 2007; Götherström et al., 2007a; Verhelst and Abs, 2009). GH replacement has been found to be effective in reversing cognitive impairments in several domains including simple motor speed, information processing speed, episodic memory, mental flexibility, verbal memory, and executive functioning in patients after TBI (High et al., 2010; Reimunde et al., 2011). GH replacement also normalizes muscle strength and increases bone mineral density (Götherström et al., 2007b, 2009), improves psychiatric functioning by ameliorating depression, intensity of interpersonal sensitivity, hostility, paranoid ideation, and anxiety (Maric et al., 2010), and improves QoL (Svensson et al., 2004b, 2007; Kreitschmann-Andermahr et al., 2008). 
Three of the Veteran participants in the T group met our criteria for hypogonadism: a total testosterone concentration less than the 5 th percentile of the reference sample together with an $\mathrm{LH}$ or FSH level below the 10th percentile reference level. In our very small sample, the occurrence of hypogonadism was found to be next highest in frequency to that of GHD, as was the case in several of the studies of PTHP after TBI from all causes in the general population (Bavisetty et al., 2008; Dusick et al., 2008; Krahulik et al., 2010; Park et al., 2010; Tanriverdi et al., 2010b).

Hypogonadism has significant deleterious consequences in addition to its adverse effects on fertility, psychosexual function, and general well being. Testosterone deficiency in males is associated with decreased energy and motivation, muscle weakness, reduced lean body mass, and impaired exercise tolerance (Agha and Thompson, 2005). In addition, a recent large epidemiological study has shown that untreated hypogonadism is associated with premature mortality secondary to cardiovascular disease (Tomlinson et al., 2001).

One mTBI participant, T-4, was found to have a highly elevated concentration of prolactin, 2.5 times higher than the next highest concentration measured in the $\mathrm{T}$ group and more than four times higher than the highest value in the DC group. Hyperprolactinemia has been causally linked with hypogonadism, specifically by reducing $\mathrm{LH}$ and FSH secretion, blocking LH stimulation of testicular testosterone secretion, and producing oligospermia by reducing FSH levels, resulting in hypoactive sexual desire and erectile dysfunction.

Prolactin is the only anterior pituitary hormone that is under predominantly inhibitory control. Its secretion is suppressed by dopamine, and in the absence of this inhibition, prolactin is released at high levels. Hyperprolactinemia frequently results from the use of antipsychotic medications that act as antagonists at dopamine D2 receptors (Holt, 2008; Inder and Castle, 2011).

Participant T-4 had been taking quetiapine, an atypical antipsychotic with fast dissociation kinetics at the D2 receptor [released from D2 within 12-24h (Seeman, 2010)] that results only in low and transient prolactin secretion (Carboni et al., 2011). It has not generally been associated with hyperprolactinemia in clinical use (Haddad and Wieck, 2004; Byerly et al., 2007; Bushe et al., 2010) although a prevalence of $22 \%$ was found in one study (Montgomery et al., 2004). It is often referred to as a dopamine-sparing antipsychotic, and although it is much less potent in elevating prolactin levels than several other antipsychotics (e.g., haloperidol and risperidone), it may have prolactin-elevating effects in some individuals, perhaps including participant T-4.

One of the Veterans with mTBI was found to have a subnormal (less than 5 th percentile) prolactin concentration. Hypoprolactinemia is rare in the general population, but it too has been associated with sexual dysfunction, primarily arteriogenic erectile dysfunction and premature ejaculation (Corona et al., 2009).

We found no evidence of dysfunction in the thyroid or adrenal axes as a result of blast mTBI. Previous studies of pituitary deficiencies after TBI from all causes have generally reported a lower prevalence of TSH and adrenocorticotropin (ACTH) deficiencies than of GH or gonadotropin deficits (Bavisetty et al., 2008; Blair, 2010; Krahulik et al., 2010). This pattern may be due in part to the location of pituitary corticotrophs and thyrotrophs in the gland's protected median wedge and their blood supply via both the long hypophysial portal vessels and the inferior hypophysial artery. GHsecreting somatotrophs, on the other hand, are anatomically more vulnerable to damage because of their location in the pituitary's exposed lateral wings and their primary dependence on vascular input from the portal system alone. Gonadotrophs are distributed throughout the anterior pituitary, and the cells in the lateral wings are relatively vulnerable.

In addition to the six participants with hormonal levels consistent with hypogonadism and/or GHD, six of the Veterans with mTBI (including one with anterior pituitary hormonal abnormalities) exhibited abnormal plasma vasopressin and/or oxytocin concentrations. Oxytocin concentrations below the 5th percentile value of the community control group were observed in four of the mTBI participants. Two of the four also exhibited indications of vasopressin deficiency as defined by vasopressin levels below the 5 th percentile of the community reference group together with urine specific gravity less than 1.003. The occurrence of deficits of both vasopressin and oxytocin in two participants suggests the possibility of disruption of the pituitary stalk or hypothalamic damage in these individuals. In addition, elevated plasma vasopressin concentrations above the reference 95th percentile were measured in two subjects.

In several studies, elevated cerebrospinal fluid (CSF) or peripheral vasopressin concentrations have been associated with PTSD, depression, schizophrenia, and other psychiatric disorders, but a causal relationship has not been established (Purba et al., 1996; van Londen et al., 1997; Coccaro et al., 1998; Merali et al., 2006; de Kloet et al., 2008; Goekoop et al., 2009; Heinrichs et al., 2009). In contrast, there is evidence from both animal and human studies for the positive association of oxytocin levels with social bonding, attenuation of stress responses in socially relevant challenges, mediation of social support, and positive social interactions (Heinrichs et al., 2009; Campbell, 2010).

Our finding of a high frequency of abnormal peripheral hormone levels after blast mTBI in this preliminary study is consistent with the investigations cited above, in which the prevalence of pituitary dysfunction fell in the $30-60 \%$ range in 11 of 22 reports. However, in general, those studies focused exclusively on anterior pituitary dysfunction. Although few studies have investigated the prevalence of chronic posterior pituitary hormonal abnormalities after TBI, most (Agha et al., 2004b, 2005; Krahulik et al., 2010), but not all (Bondanelli et al., 2004), found significant evidence of damage in that lobe as well. In this study we found significant anterior pituitary dysfunction in $23.1 \%$ of Veterans with mTBI and abnormal posterior pituitary hormone levels in $23.1 \%$ of this group as well. In contrast, the prevalence of hypopituitarism in the general adult population ranges between 290 and 455 cases per million (Regal et al., 2001).

The only other ongoing study of hypopituitarism after blast mTBI of which we are aware recently reported preliminary results based on two retrospective chart reviews. Of 147 Marines with blast-related mTBI screened approximately 1 year or more after injury, 25\% were found to have abnormal levels of one or more anterior pituitary hormones (Stokes and Gallagher, 2011).

The Veteran groups in this study are highly similar in demographic characteristics and share the common experience of 
deployment under highly stressful and dangerous conditions accentuated by extreme heat and the burden of heavy equipment even when not actively engaged in combat. Despite these commonalities, the experience of blast trauma and the combat situations in which these exposures occur have major long-term consequences well beyond those of deployment to Iraq or Afghanistan. The considerable overlap between the constellations of symptoms typical of chronic hypopituitarism and persistent post-concussive symptoms (PPCS), in addition to the similarities of both to PTSD, make accurate diagnosis of the etiology, progression, and identifiable differences between the conditions of critical importance for successful treatment, recovery, and rehabilitation (Masel, 2005).

The consequences of undiagnosed and untreated pituitary hormone deficiencies are manifold and significant and include diminished QoL, cognitive deficiencies, fatigue, sleep disturbance, sexual dysfunction, deleterious changes in metabolism and body composition, behavioral and psychiatric problems including anxiety, irritability, social isolation, depression, and increased cardiovascular mortality. PTHP, unlike PTSD and PPCS, is readily treatable if correctly diagnosed, and many of its symptoms can be reversed or ameliorated with appropriate hormone replacement therapy.

Several of the authors of previous studies of hypopituitarism after TBI have advocated routine endocrine evaluation after brain injury (Masel, 2004; Leal-Cerro et al., 2005; Schneider et al., 2005; Urban et al., 2005; Powner et al., 2006; Behan and Agha, 2007; Ho, 2007; Behan et al., 2008; Tanriverdi et al., 2008b, 2010b; Blair, 2010; Krahulik et al., 2010; Park et al., 2010). A recent review of the literature (Guerrero and Alfonso, 2010) stated that because "many of the symptoms of hypopituitarism are similar to those of TBI, it is important to make clinicians caring for combat veterans aware of its occurrence... All patients who had a TBI of any severity, should undergo baseline hormonal evaluation."

\section{REFERENCES}

Agha, A., Rogers, B., Sherlock, M., O'Kelly, P., Tormey, W., Phillips, J., and Thompson, C. J. (2004a). Anterior pituitary dysfunction in survivors of traumatic brain injury. J. Clin. Endocrinol. Metab. 89, 4929-4936.

Agha, A., Thornton, E., O'Kelly, P., Tormey, W., Phillips, J., and Thompson, C. J. (2004b). Posterior pituitary dysfunction after traumatic brain injury. J. Clin. Endocrinol. Metab. 89, 5987-5992.

Agha, A., Sherlock, M., Phillips, J., Tormey, W., and Thompson, C. J. (2005). The natural history of posttraumatic neurohypophysial dysfunction. Eur. J. Endocrinol. 152, 371-377.

Agha, A., and Thompson, C. J. (2005). High risk of hypogonadism after traumatic brain injury: clinical implications. Pituitary 8, 245-249.

Aimaretti, G., Ambrosio, M. R., Di Somma, C., Fusco, A., Cannavò, S., Gasperi, M., Scaroni, C., De Marinis, L., Benvenga, S., degli Uberti, E. C., Lombardi, G., Mantero, F.,
Martino, E., Giordano, G., and Ghigo, E. (2004). Traumatic brain injury and subarachnoid haemorrhage are conditions at high risk for hypopituitarism: screening study at 3 months after the brain injury. Clin. Endocrinol. (Oxf.) 61, 320-326.

Aimaretti, G., Ambrosio, M. R., Di Somma, C., Gasperi, M., Cannavò, S., Scaroni, C., Fusco, A., Del Monte, P., De Menis, E., Faustini-Fustini, M., Grimaldi, F., Logoluso, F., Razzore, P., Rovere, S., Benvenga, S., degli Uberti, E. C., De Marinis, L., Lombardi, G., Mantero, F., Martino, E., Giordano, G., and Ghigo, E. (2005). Residual pituitary function after brain injury-induced hypopituitarism: a prospective 12-month study. J. Clin. Endocrinol. Metab. 90, 6085-6092.

American Congress of Rehabilitation Medicine. (1993). Definition of mild traumatic brain injury. J. Head Trauma Rehabil. 8, 86-87.

Bavisetty, S., McArthur, D. L., Dusick, J. R., Wang, C., Cohan, P., Boscardin, W. J., Swerdloff, R., Levin, H.,

To our knowledge, this is the first published study of basal hormonal evaluation of combat Veterans with blast mTBI, and our preliminary findings of PTHP in $42 \%$ of study participants supports the advisability of routine screening for hypopituitarism after brain injury in both military and civilian populations. Routine provocative testing for sAI and for GHD, the most frequently observed chronic endocrine disorder resulting from TBI, is neither economically nor practically viable. However, measurement of basal concentrations of a panel of pituitary and target-organ hormones similar to those performed here may provide valuable preliminary indications of those individuals most likely to benefit from further clinical evaluation. Similar preliminary screening for pituitary dysfunction after blast concussion shows promise for appropriately directing diagnostic and therapeutic decisions that otherwise may remain unconsidered and for markedly facilitating recovery and rehabilitation.

\section{ACKNOWLEDGMENTS}

We gratefully acknowledge the skillful assistance of Carl Sikkema for laboratory work, Carol Xiang and Daniel Morelli for data management, Molly Chinn and Alka Goyal for administrative guidance, Natalia Czajkiewicz for graphic design, and Dr. Leanne Madre for significant contributions in shaping the manuscript into its final form. The work was supported by U.S. Department of Defense Congressionally Directed Medical Research Program Concept Award PT090753; the Geriatric Research, Education and Clinical Center, and the Research and Development Service of the VA Puget Sound Health Care System; the VA Northwest Network Mental Illness Research, Education and Clinical Center; the Seattle Institute for Biomedical and Clinical Research; the University of Washington Alzheimer's Disease Research Center NIA AG05136; and an anonymous foundation.

Chang, D. J., Muizelaar, J. P., and Kelly, D. F. (2008). Chronic hypopituitarism after traumatic brain injury: risk assessment and relationship to outcome. Neurosurgery 62 1080-1093; discussion 1093-1084.

Behan, L. A., and Agha, A. (2007). Endocrine consequences of adult traumatic brain injury. Horm. Res. 68(Suppl. 5), 18-21.

Behan, L. A., Phillips, J., Thompson, C. J., and Agha, A. (2008). Neuroendocrine disorders after traumatic brain injury. J. Neurol. Neurosurg. Psychiatr. 79, 753-759.

Berg, C., Oeffner, A., Schumm-Draeger P. M., Badorrek, F., Brabant, G., Gerbert, B., Bornstein, S., Zimmermann, A., Weber, M., Broecker-Preuss, M., Mann, K., and Herrmann, B. L. (2010). Prevalence of anterior pituitary dysfunction in patients following traumatic brain injury in a German multi-centre screening program. Exp. Clin. Endocrinol. Diabetes 118, 139-144.

Blair, J. C. (2010). Prevalence, natural history and consequences of posttraumatic hypopituitarism: a case for endocrine surveillance. $\mathrm{Br} . \mathrm{J}$ Neurosurg. 24, 10-17.

Bondanelli, M., De Marinis, L., Ambrosio, M. R., Monesi, M., Valle, D., Zatelli, M. C., Fusco, A., Bianchi, A., Farneti, M., and Degli Uberti, E. C. (2004). Occurrence of pituitary dysfunction following traumatic brain injury. J. Neurotrauma 21, 685-696.

Bushe, C., Sniadecki, J., Bradley, A. J., and Poole Hoffmann, V. (2010). Comparison of metabolic and prolactin variables from a six-month randomised trial of olanzapine and quetiapine in schizophrenia. J. Psychopharmacol. (Oxford) 24, 1001-1009.

Bushnik, T., Englander, J., and Katznelson, L. (2007). Fatigue after TBI: association with neuroendocrine abnormalities. Brain Inj. 21, 559-566.

Byerly, M., Suppes, T., Tran, Q. V., and Baker, R. A. (2007). Clinical implications of antipsychotic-induced hyperprolactinemia in patients with schizophrenia spectrum or bipolar spectrum disorders: recent 
developments and current perspectives. J. Clin. Psychopharmacol. 27, 639-661.

Campbell, A. (2010). Oxytocin and human social behavior. Pers. Soc. Psychol. Rev. 14, 281-295.

Carboni, L., Negri, M., Michielin, F., Bertani, S., Fratte, S. D., Oliosi, B., and Cavanni, P. (2011). Slow dissociation of partial agonists from the D2 receptor is linked to reduced prolactin release. Int. J. Neuropsychopharmacol. doi: 10.1017/S1461145711000824. [Epub ahead of print].

Coccaro, E. F., Kavoussi, R. J., Hauger, R. L., Cooper, T. B., and Ferris, C. F. (1998). Cerebrospinal fluid vasopressin levels: correlates with aggression and serotonin function in personality-disordered subjects. Arch. Gen. Psychiatry 55, 708-714.

Colao, A. (2008). The GH-IGF-I axis and the cardiovascular system: clinical implications. Clin. Endocrinol. (Oxf.) 69, 347-358.

Colao, A., Di Somma, C., Savanelli, M. C., De Leo, M., and Lombardi, G. (2006a). Beginning to end: cardiovascular implications of growth hormone (GH) deficiency and GH therapy. Growth Horm. IGF Res. 16(Suppl. A), S41-48.

Colao, A., Di Somma, C., Spiezia, S., Rota, F., Pivonello, R., Savastano, S., and Lombardi, G. (2006b). The natural history of partial growth hormone deficiency in adults: a prospective study on the cardiovascular risk and atherosclerosis. J. Clin. Endocrinol. Metab. 91, 2191-2200.

Corneli, G., Di Somma, C., Prodam, F., Bellone, J., Bellone, S., Gasco, V., Baldelli, R., Rovere, S., Schneider, H. J., Gargantini, L., Gastaldi, R., Ghizzoni, L., Valle, D., Salerno, M., Colao, A., Bona, G., Ghigo, E., Maghnie, M., and Aimaretti, G. (2007). Cut-off limits of the GH response to GHRH plus arginine test and IGF-I levels for the diagnosis of GH deficiency in late adolescents and young adults. Eur. J. Endocrinol. 157, 701-708.

Corona, G., Mannucci, E., Jannini, E. A., Lotti, F., Ricca, V., Monami, M., Boddi, V., Bandini, E., Balercia, G., Forti, G., and Maggi, M. (2009). Hypoprolactinemia: a new clinical syndrome in patients with sexual dysfunction. J. Sex. Med. 6, 1457-1466.

de Kloet, C. S., Vermetten, E., Geuze, E., Wiegant, V. M., and Westenberg, H. G. (2008). Elevated plasma arginine vasopressin levels in veterans with posttraumatic stress disorder. $J$. Psychiatr. Res. 42, 192-198.
Department of Veterans Affairs/Department of Defense. (2009). VA/DoD Clinical Practice Guideline for Management of Concussion/Mild Traumatic Brain Injury (mTBI). Washington, DC: Department of Veterans Affairs, Department of Defense.

Doty, R. L., Marcus, A., and Lee, W. W. (1996). Development of the 12item cross-cultural smell identification test (CC-SIT). Laryngoscope 106, 353-356

Dusick, J. R., Wang, C., Cohan, P., Swerdloff, R., and Kelly, D. F. (2008). Chapter 1: pathophysiology of hypopituitarism in the setting of brain injury. Pituitary. doi: 10.1007/s11102-008-0130-6. [Epub ahead of print].

Englander, J., Bushnik, T., Oggins, J., and Katznelson, L. (2010). Fatigue after traumatic brain injury: association with neuroendocrine, sleep, depression and other factors. Brain Inj. 24, 1379-1388.

Falleti, M. G., Maruff, P., Burman, P., and Harris, A. (2006). The effects of growth hormone (GH) deficiency and GH replacement on cognitive performance in adults: a meta-analysis of the current literature. Psychoneuroendocrinology 31, 681-691.

Faul, M., Xu, L., Wald, M. M., and Coronado, V. G. (2010). Traumatic Brain Injury in the United States: Emergency Department Visits, Hospitalizations and Deaths 2002-2006. Atlanta, GA: Centers for Disease Control and Prevention, National Center for Injury Prevention and Control.

Goekoop, J. G., De Winter, R. F., Wolterbeek, R., Spinhoven, P., Zitman, F. G., and Wiegant, V. M. (2009). Reduced cooperativeness and reward-dependence in depression with above-normal plasma vasopressin concentration. J. Psychopharmacol. (Oxford) 23, 891-897.

Götherström, G., Bengtsson, B.- $\AA$. Bosaeus, I., Johannsson, G., and Svensson, J. (2007a). A 10-year, prospective study of the metabolic effects of growth hormone replacement in adults. J. Clin. Endocrinol. Metab. 92, 1442-1445.

Götherström, G., Bengtsson, B.-Å., Bosaeus, I., Johannsson, G., and Svensson, J. (2007b). Ten-year GH replacement increases bone mineral density in hypopituitary patients with adult onset GH deficiency. Eur. J. Endocrinol. 156, 55-64.

Götherström, G., Elbornsson, M., Stibrant-Sunnerhagen, K., Bengtsson, B.-Å., Johannsson, G., and Svensson, J. (2009). Ten years of growth hormone (GH) replacement normalizes muscle strength in $\mathrm{GH}$ deficient adults. J. Clin. Endocrinol. Metab. 94, 809-816.

Guerrero, A. F., and Alfonso, A. (2010). Traumatic brain injuryrelated hypopituitarism: a review and recommendations for screening combat veterans. Mil. Med. 175 , 574-580.

Haddad, P. M., and Wieck, A. (2004). Antipsychotic-induced hyperprolactinaemia: mechanisms, clinical features and management. Drugs 64, 2291-2314.

Hadjadj, S., Faure-Gerard, C., Ragot, S., Millet, C., Duengler, F., Torremocha, F., Chatellier, G., Bataille, B., and Marechaud, R. (2007). Diagnostic strategy for growth hormone deficiency: relevance of IGF-1 determination as a screening test. Ann. Endocrinol. (Paris) 68, 449-455.

Hartman, M. L., Crowe, B. J., Biller, B. M. K., Ho, K. K., Clemmons, D. R. and Chipman, J. J. (2002). Which patients do not require a GH stimulation test for the diagnosis of adult GH deficiency? J. Clin. Endocrinol. Metab. 87, 477-485.

Heinrichs, M., Von Dawans, B., and Domes, G. (2009). Oxytocin, vasopressin, and human social behavior. Front. Neuroendocrinol. 30, 548-557.

High, W. M. Jr., Briones-Galang, M., Clark, J. A., Gilkison, C., Mossberg, K. A., Zgaljardic, D. J., Masel, B. E., and Urban, R. J. (2010). Effect of growth hormone replacement therapy on cognition after traumatic brain injury. J. Neurotrauma 27 1565-1575.

Ho, K. K. Y. (2007). Consensus guidelines for the diagnosis and treatment of adults with $\mathrm{GH}$ deficiency II: a statement of the GH research society in association with the European society for pediatric endocrinology, Lawson Wilkins society, European society of endocrinology, Japan endocrine society, and endocrine society of Australia. Eur. J. Endocrinol. 157, 695-700.

Holmin, S., and Mathiesen, T. (1999). Long-term intracerebral inflammatory response after experimental focal brain injury in rat. Neuroreport 10, 1889-1891.

Holt, R. I. (2008). Medical causes and consequences of hyperprolactinaemia. A context for psychiatrists. J. Psychopharmacol. (Oxford) 22, 28-37.

Inder, W. J., and Castle, D. (2011). Antipsychotic-induced hyperprolactinaemia. Aust. N. Z. J. Psychiatry 45, 830-837.
Juul, A., Kastrup, K. W., Pedersen, S. A., and Skakkebaek, N. E. (1997). Growth hormone (GH) provocative retesting of 108 young adults with childhood-onset GH deficiency and the diagnostic value of insulin-like growth factor I (IGF-I) and IGF-binding protein-3. J. Clin Endocrinol. Metab. 82, 1195-1201.

Kasturi, B. S., and Stein, D. G. (2009). Traumatic brain injury causes longterm reduction in serum growth hormone and persistent astrocytosis in the cortico-hypothalamopituitary axis of adult male rats. $J$. Neurotrauma 26, 1315-1324.

Kelestimur, F., Tanriverdi, F., Atmaca, H., Unluhizarci, K., Selcuklu, A., and Casanueva, F. F. (2004). Boxing as a sport activity associated with isolated GH deficiency. J. Endocrinol. Invest. 27, RC28-RC32.

Kelly, D. F., Gonzalo, I. T., Cohan, P., Berman, N., Swerdloff, R., and Wang, C. (2000). Hypopituitarism following traumatic brain injury and aneurysmal subarachnoid hemorrhage: a preliminary report. $\mathrm{J}$. Neurosurg. 93, 743-752.

Kelly, D. F., MacArthur, D. L., Levin, H., Swimmer, S., Dusick, J. R., Cohan, P. Wang, C., and Swerdloff, R. (2006). Neurobehavioral and quality of life changes associated with growth hormone insufficiency after complicated mild, moderate, or severe traumatic brain injury. J. Neurotrauma 23, 928-942.

Klose, M., Juul, A., Struck, J., Morgenthaler, N. G., Kosteljanetz, M., and Feldt-Rasmussen, U. (2007). Acute and long-term pituitary insufficiency in traumatic brain injury: a prospective single-centre study. Clin. Endocrinol. (Oxf.) 67, 598-606.

Kokshoorn, N. E., Smit, J. W., Nieuwlaat, W. A., Tiemensma, J., Bisschop, P. H., Groote Veldman, R., Roelfsema, F., Franken, A. A., Wassenaar, M. J., Biermasz, N. R., Romijn, J. A. and Pereira, A. M. (2011). Low prevalence of hypopituitarism after traumatic brain injury: a multicenter study. Eur. J. Endocrinol. 165, 225-231.

Kokshoorn, N. E., Wassenaar, M. J., Biermasz, N. R., Roelfsema, F., Smit, J. W., Romijn, J. A., and Pereira, A. M. (2010). Hypopituitarism following traumatic brain injury: prevalence is affected by the use of different dynamic tests and different normal values. Eur. J. Endocrinol. 162, 11-18.

Krahulik, D., Zapletalova, J., Frysak, Z., and Vaverka, M. (2010). Dysfunction of hypothalamic-hypophyseal axis after traumatic brain injury 
in adults. J. Neurosurg. 113, 581-584.

Kreitschmann-Andermahr, I., Poll, E. M., Reineke, A., Gilsbach, J. M., Brabant, G., Buchfelder, M., Fassbender, W., Faust, M., Kann, P. H., and Wallaschofski, H. (2008). Growth hormone deficient patients after traumatic brain injury - baseline characteristics and benefits after growth hormone replacement - an analysis of the German KIMS database. Growth Horm. IGF Res. 18, 472-478.

Leal-Cerro, A., Flores, J. M., Rincon, M., Murillo, F., Pujol, M., Garcia-Pesquera, F., Dieguez, C., and Casanueva, F. F. (2005). Prevalence of hypopituitarism and growth hormone deficiency in adults longterm after severe traumatic brain injury. Clin. Endocrinol. (Oxf.) 62, 525-532.

Lieberman, S. A., Oberoi, A. L., Gilkison, C. R., Masel, B. E., and Urban, R. J. (2001). Prevalence of neuroendocrine dysfunction in patients recovering from traumatic brain injury. J. Clin. Endocrinol. Metab. 86, 2752-2756.

Lu, J., Goh, S. J., Tng, P. Y., Deng, Y. Y., Ling, E. A., and Moochhala, S. (2009). Systemic inflammatory response following acute traumatic brain injury. Front. Biosci. 14, 3795-3813.

Maghnie, M., Aimaretti, G., Bellone, S., Bona, G., Bellone, J., Baldelli, R., De Sanctis, C., Gargantini, L., Gastaldi, R., Ghizzoni, L., Secco, A., Tinelli, C., and Ghigo, E. (2005). Diagnosis of GH deficiency in the transition period: accuracy of insulin tolerance test and insulin-like growth factorI measurement. Eur. J. Endocrinol. $152,589-596$.

Maric, N. P., Doknic, M., Pavlovic, D., Pekic, S., Stojanovic, M., JasovicGasic, M., and Popovic, V. (2010). Psychiatric and neuropsychological changes in growth hormonedeficient patients after traumatic brain injury in response to growth hormone therapy. J. Endocrinol. Invest. 33, 770-775.

Martínez-Martín, P., Gil-Nagel, A., Gracia, L. M., Gómez, J. B., MartínezSarriés, J., and Bermejo, F. (1994). Unified Parkinson's disease rating scale characteristics and structure. The Cooperative Multicentric Group. Mov. Disord. 9, 76-83.

Masel, B. E. (2004). Rehabilitation and hypopituitarism after traumatic brain injury. Growth Horm. IGF Res. 14(Suppl. A), S108-S113.

Masel, B. E. (2005). Traumatic brain injury induced hypopituitarism: the need and hope of rehabilitation. Pituitary 8, 263-266.

McGauley, G. A. (1989). Quality of life assessment before and after growth hormone treatment in adults with growth hormone deficiency. Acta Paediatr. Scand. Suppl. 356, 70-72; discussion 73-74.

Merali, Z., Kent, P., Du, L., Hrdina, P., Palkovits, M., Faludi, G., Poulter, M. O., Bédard, T., and Anisman, H. (2006). Corticotropinreleasing hormone, arginine vasopressin, gastrin-releasing peptide, and neuromedin B alterations in stress-relevant brain regions of suicides and control subjects. Biol. Psychiatry 59, 594-602.

Military Health System. (2011). DoD Worldwide Numbers for Traumatic Brain Injury. Available at: http://www.health.mil/ Research/TBI_Numbers.aspx [accessed].

Montgomery, J., Winterbottom, E., Jessani, M., Kohegyi, E., Fulmer, J., Seamonds, B., and Josiassen, R. C. (2004). Prevalence of hyperprolactinemia in schizophrenia: association with typical and atypical antipsychotic treatment. J. Clin. Psychiatry 65, 1491-1498.

Mossberg, K. A., Masel, B. E., Gilkison, C. R., and Urban, R. J. (2008). Aerobic capacity and growth hormone deficiency after traumatic brain injury. J. Clin. Endocrinol. Metab. 93, 2581-2587.

National Center for Injury Prevention and Control. (2003). Report to Congress on Mild Traumatic Brain Injury in the United States: Steps to Prevent a Serious Public Health Problem. Atlanta, GA: Centers for Disease Control and Prevention.

Park, K. D., Kim, D. Y., Lee, J. K., Nam, H.-S., and Park, Y.-G. (2010). Anterior pituitary dysfunction in moderate-to-severe chronic traumatic brain injury patients and the influence on functional outcome. Brain Inj. 24, 1330-1335.

Pavlovic, D., Pekic, S., Stojanovic, M., Zivkovic, V., Djurovic, B., Jovanovic, V., Miljic, N., Medic-Stojanoska, M., Doknic, M., Miljic, D., Djurovic, M., Casanueva, F., and Popovic, V. (2010). Chronic cognitive sequelae after traumatic brain injury are not related to growth hormone deficiency in adults. Eur. J. Neurol. 17, 696-702.

Popovic, V., Pekic, S., Pavlovic, D., Maric, N., Jasovic-Gasic, M., Djurovic, B., Medic Stojanoska, M., Zivkovic, V., Stojanovic, M., Doknic, M., Milic, N., Djurovic, M., Dieguez,
C., and Casanueva, F. F. (2004). Hypopituitarism as a consequence of traumatic brain injury (TBI) and its possible relation with cognitive disabilities and mental distress. J. Endocrinol. Invest. 27, 1048-1054.

Powner, D. J., Boccalandro, C., Alp, M. S., and Vollmer, D. G. (2006). Endocrine failure after traumatic brain injury in adults. Neurocrit. Care 5, 61-70.

Prodam, F., Pagano, L., Corneli, G., Golisano, G., Belcastro, S., Busti, A. Gasco, V., Beccuti, G., Grottoli, S., Di Somma, C., Colao, A., Ghigo, E., and Aimaretti, G. (2008). Update on epidemiology, etiology, and diagnosis of adult growth hormone deficiency. $J$. Endocrinol. Invest. 31, 6-11.

Purba, J. S., Hoogendijk, W. J., Hofman, M. A., and Swaab, D. F. (1996) Increased number of vasopressinand oxytocin-expressing neurons in the paraventricular nucleus of the hypothalamus in depression. Arch. Gen. Psychiatry 53, 137-143.

R Development Core Team (2011). R: A Language and Environment for Statistical Computing. R Foundation for Statistical Computing, Vienna, Austria. Available at: http://www.Rproject.org/

Regal, M., Páramo, C., Sierra, S. M., and García-Mayor, R. V. (2001). Prevalence and incidence of hypopituitarism in an adult Caucasian population in northwestern Spain. Clin. Endocrinol. (Oxf.) 55, 735-740.

Reimunde, P., Quintana, A., Castanon, B., Casteleiro, N., Vilarnovo Z., Otero, A., Devesa, A., OteroCepeda, X. L., and Devesa, J. (2011). Effects of growth hormone (GH) replacement and cognitive rehabilitation in patients with cognitive disorders after traumatic brain injury. Brain Inj. 25 , 65-73.

Rosén, T., Wirén, L., Wilhelmsen, L. Wiklund, I., and Bengtsson, B.A. (1994). Decreased psychological well-being in adult patients with growth hormone deficiency. Clin. Endocrinol. (Oxf.) 40, 111-116.

Schneider, H. J., Schneider, M. Kreitschmann-Andermahr, I. Tuschy, U., Wallaschofski, H., Fleck, S., Faust, M., Renner, C. I. E. Kopczak, A., Saller, B., Buchfelder, M., Jordan, M., and Stalla, G. K. (2011). Structured assessment of hypopituitarism after traumatic brain injury and aneurysmal subarachnoid hemorrhage in 1242 patients: the German interdisciplinary database. J. Neurotrauma 28 1693-1698.
Schneider, H. J., Schneider, M., Saller, B., Petersenn, S., Uhr, M., Husemann, B., Von Rosen, F., and Stalla, G. K. (2006). Prevalence of anterior pituitary insufficiency 3 and 12 months after traumatic brain injury. Eur. J. Endocrinol. 154, 259-265.

Schneider, M., Schneider, H. J., and Stalla, G. K. (2005). Anterior pituitary hormone abnormalities following traumatic brain injury. J. Neurotrauma 22, 937-946.

Schneider, M., Schneider, H. J., Yassouridis, A., Saller, B., Von Rosen, F., and Stalla, G. K. (2008). Predictors of anterior pituitary insufficiency after traumatic brain injury. Clin. Endocrinol. (Oxf.) 68, 206-212.

Seeman, P. (2010). Dopamine D2 receptors as treatment targets in schizophrenia. Clin. Schizophr. Relat. Psychoses 4, 56-73.

Srinivasan, L., Roberts, B., Bushnik, T., Englander, J., Spain, D. A., Steinberg, G. K., Ren, L., Sandel, M. E., Al-Lawati, Z., Teraoka, J., Hoffman, A. R., and Katznelson, L. (2009). The impact of hypopituitarism on function and performance in subjects with recent history of traumatic brain injury and aneurysmal subarachnoid haemorrhage. Brain Inj. 23, 639-648.

Stokes, A., and Gallagher, J. (2011). "Pituitary deficiencies in active duty military patients with a history of mild traumatic brain injury," in $3 r d$ Federal Interagency Conference on Traumatic Brain Injury, Washington, DC.

Svensson, J., Bengtsson, B.-Å., Rosén, T., Odén, A., and Johannsson, G. (2004a). Malignant disease and cardiovascular morbidity in hypopituitary adults with or without growth hormone replacement therapy. J. Clin. Endocrinol. Metab. 89, 3306-3312.

Svensson, J., Mattsson, A., Rosén, T. Wirén, L., Johannsson, G., Bengtsson, B.-Å., and Koltowska Häggström, M. (2004b). Three-years of growth hormone $(\mathrm{GH})$ replacement therapy in GH-deficient adults: effects on quality of life, patientreported outcomes and healthcare consumption. Growth Horm. IGF Res. 14, 207-215.

Svensson, J., Finer, N., Bouloux, P., Bevan, J., Jonsson, B., Mattsson, A. F., Lundberg, M., Harris, P. E., Koltowska-Häggström, M., and Monson, J. P. (2007). Growth hormone $(\mathrm{GH})$ replacement therapy in GH deficient adults: predictors of one-year metabolic and clinical 
response. Growth Horm. IGF Res. 17, 67-76.

Tanielian, T. L., Jaycox, L., and RAND Corporation. (2008). Invisible Wounds of War: Psychological and Cognitive Injuries, their Consequences, and Services to Assist Recovery. Santa Monica, CA: RAND.

Tanriverdi, F., Agha, A., Aimaretti, G., Casanueva, F. F., Kelestimur, F., Klose, M., Masel, B. E., Pereira, A. M., Popovic, V., and Schneider, H. J. (2011). Manifesto for the current understanding and management of traumatic brain injury-induced hypopituitarism. J. Endocrinol. Invest. 34, 541-543.

Tanriverdi, F., Senyurek, H., Unluhizarci, K., Selcuklu, A., Casanueva, F. F., and Kelestimur, F. (2006). High risk of hypopituitarism after traumatic brain injury: a prospective investigation of anterior pituitary function in the acute phase and 12 months after trauma. J. Clin. Endocrinol. Metab. 91, 2105-2111.

Tanriverdi, F., Taheri, S., Ulutabanca, H., Caglayan, A. O., Ozkul, Y., Dundar, M., Selcuklu, A., Unluhizarci, K., Casanueva, F. F., and Kelestimur, F. (2008a). Apolipoprotein E3/E3 genotype decreases the risk of pituitary dysfunction after traumatic brain injury due to various causes: preliminary data. J. Neurotrauma 25 , 1071-1077.

Tanriverdi, F., Ulutabanca, H., Unluhizarci, K., Selcuklu, A., Casanueva, F. F., and Kelestimur, F. (2008b). Three years prospective investigation of anterior pituitary function after traumatic brain injury: a pilot study. Clin. Endocrinol. (Oxf.) 68, 573-579.

Tanriverdi, F., Unluhizarci, K., Kocyigit, I., Tuna, I. S., Karaca, Z., Durak, A. C., Selcuklu, A., Casanueva, F. F., and Kelestimur, F. (2008c). Brief communication: pituitary volume and function in competing and retired male boxers. Ann. Intern. Med. 148, 827-831.

Tanriverdi, F., Unluhizarci, K., Coksevim, B., Selcuklu, A., Casanueva, F. F., and Kelestimur, F. (2007). Kickboxing sport as a new cause of traumatic brain injury-mediated hypopituitarism. Clin. Endocrinol. (Oxf.) 66, 360-366.

Tanriverdi, F., Unluhizarci, K., Karaca, Z., Casanueva, F. F., and Kelestimur, F. (2010a). Hypopituitarism due to sports related head trauma and the effects of growth hormone replacement in retired amateur boxers. Pituitary 13, 111-114.

Tanriverdi, F., Unluhizarci, K., and Kelestimur, F. (2010b). Pituitary function in subjects with mild traumatic brain injury: a review of literature and proposal of a screening strategy. Pituitary 13, 146-153.

Terrio, H., Brenner, L. A., Ivins, B. J., Cho, J. M., Helmick, K., Schwab, K., Scally, K., Bretthauer, R., and Warden, D. (2009). Traumatic brain injury screening: preliminary findings in a US Army Brigade Combat Team. J. Head Trauma Rehabil. 24, 14-23.

Tomlinson, J. W., Holden, N., Hills, R. K., Wheatley, K., Clayton, R. N., Bates, A. S., Sheppard, M. C., and Stewart, P. M. (2001). Association between premature mortality and hypopituitarism. West Midlands Prospective Hypopituitary Study Group. Lancet 357, 425-431.

Urban, R. J., Harris, P., and Masel, B. (2005). Anterior hypopituitarism following traumatic brain injury. Brain Inj. 19, 349-358.

Van Cauter, E., Kerkhofs, M., Caufriez, A., Van Onderbergen, A., Thorner, M. O., and Copinschi, G. (1992) A quantitative estimation of growth hormone secretion in normal man: reproducibility and relation to sleep and time of day. J. Clin. Endocrinol. Metab. 74, 1441-1450.

van der Eerden, A. W., Twickler, M. T., Sweep, F. C., Beems, T., Hendricks, H. T., Hermus, A. R., and Vos, P. E. (2010). Should anterior pituitary function be tested during follow-up of all patients presenting at the emergency department because of traumatic brain injury? Eur. J. Endocrinol. 162, 19-28.

van Londen, L., Goekoop, J. G., Van Kempen, G. M. V., FrankhuijzenSierevogel, A. C., Wiegant, V. M., Van Der Velde, E. A., and De Wied, D. (1997). Plasma levels of arginine vasopressin elevated in patients with major depression. Neuropsychopharmacology 17, 284-292.

Verhelst, J., and Abs, R. (2009). Cardiovascular risk factors in hypopituitary GH-deficient adults. Eur. J. Endocrinol. 161(Suppl. 1), S41-S49.

Zgaljardic, D. J., Guttikonda, S., Grady, J. J., Gilkison, C. R., Mossberg, K. A., High, W. M. Jr., Masel, B. E. and Urban, R. J. (2011). Serum IGF-1 concentrations in a sample of patients with traumatic brain injury as a diagnostic marker of growth hormone secretory response to glucagon stimulation testing. Clin. Endocrinol. (Oxf.) 74, 365-369.

Ziebell, J. M., and Morganti-Kossmann, M. C. (2010). Involvement of proand anti-inflammatory cytokines and chemokines in the pathophysiology of traumatic brain injury. Neurotherapeutics 7, 22-30.

Conflict of Interest Statement: The authors declare that the research was conducted in the absence of any commercial or financial relationships that could be construed as a potential conflict of interest.

Received: 02 December 2011; paper pending published: 27 December 2011; accepted: 17 January 2012; published online: 07 February 2012.

Citation: Wilkinson CW, Pagulayan KF, Petrie EC, Mayer CL, Colasurdo EA, Shofer JB, Hart KL, Hoff $D$, Tarabochia MA and Peskind ER (2012) High prevalence of chronic pituitary and target-organ hormone abnormalities after blast-related mild traumatic brain injury. Front. Neur. 3:11. doi: 10.3389/fneur.2012.00011

This article was submitted to Frontiers in Neurotrauma, a specialty of Frontiers in Neurology.

Copyright (c) 2012 Wilkinson, Pagulayan, Petrie, Mayer, Colasurdo, Shofer, Hart, Hoff, Tarabochia and Peskind. This is an open-access article distributed under the terms of the Creative Commons Attribution Non Commercial License, which permits non-commercial use, distribution, and reproduction in other forums, provided the original authors and source are credited. 